\title{
Embryonic Development of Curimba (Prochilodus Lineatus) Submitted to Soluble Biodiesel Fractions
}

\author{
Dênio G. S. de Oliveira ${ }^{1}$, Luis D. S. Murgas ${ }^{2} \&$ Daniella A. J. Paula ${ }^{2}$ \\ ${ }^{1}$ Institute of Health Sciences, University Center of Formiga, Formiga, MG, Brazil \\ ${ }^{2}$ Department of Veterinary Medicine, Federal University of Lavras, UFLA, Lavras, MG, Brazil \\ Correspondence: Luis D. S. Murgas, Department of Veterinary Medicine, Federal University of Lavras, UFLA, \\ P.O. Box 3037, Lavras, MG, 37200-000, Brazil. E-mail: 1smurgas@prp.ufla.br
}

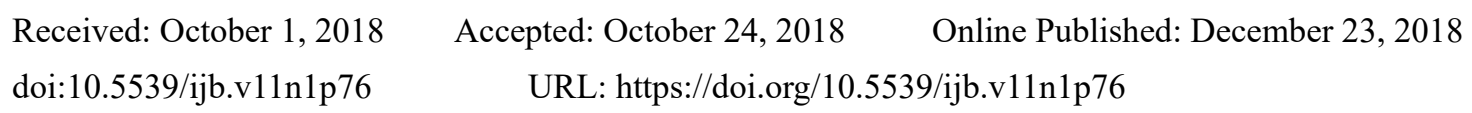

\begin{abstract}
The present study aimed to investigate the effect of different soluble biodiesel fraction (SBF) concentrations from burnt soy oil on the embryonic development of curimba (Prochilodus lineatus). The embryos were obtained from semi-natural spawning, collected and transferred to an experimental nursery, in duplicate, under constant aeration, containing different SBF concentrations: treatment I (control), treatment II (0.0645 g.L $\left.\mathrm{L}^{-1}\right)$, treatment III (0.129 g. $\left.\mathrm{L}^{-1}\right)$, treatment IV $\left(0.645\right.$ g. $\left.\mathrm{L}^{-1}\right)$, treatment V $\left(1.29\right.$ g.L $\left.{ }^{-1}\right)$ and treatment VI $\left(6.45\right.$ g.L $\left.\mathrm{L}^{-1}\right)$. Mean water quality variables were temperature $23.0 \pm 0.1^{\circ} \mathrm{C}$, dissolved oxygen $4.58 \pm 0.34 \mathrm{mg} / \mathrm{L}$ and $\mathrm{pH} 7.3 \pm 0.1$. Fish fertilization rates ranged from 50.88 to $81.61 \%$, undergoing alterations beginning at treatment IV $(\mathrm{p}<0.05)$. From the tenth hour post-fertilization, delays in embryonic development were observed in relation to the control treatment. Hatching rates ranged from 7.56 to $46.26 \%$, with all groups statistically differing from group I (controls). It is concluded that the different soluble biodiesel fractions interfere in curimba (Prochilodus lineatus) embryonic development.
\end{abstract}

Keywords: Biofuel, Fertilization, Hatching, Toxicity, Yolk Height

\section{Introduction}

The search for the interaction between economic development and ecosystem preservation is termed sustainability. Its fundamental points aim at survival on Earth, both now and in the future. Examples of this concept are the measures that have been adopted and the investments being made in Brazil in relation to biofuels, a renewable energy source. Although this source does not display the minimum autonomy to replace petroleum, it at least aims to reduce its use.

Biofuel originates from renewable biological sources based on vegetable oil or animal fat, and displays physical and chemical similarities to mineral diesel. This energy source consists of fatty acids esters, alkyl esters (methyl, ethyl or propyl) and long chain carboxylic acids (Teixeira \& Touil, 2010), and is a biodegradable fuel commonly obtained by transesterification, a chemical reaction between lipids (vegetable oils or short chain fats) and acidic or basic alcohols. Biofuel is considered a less polluting fuel than petroleum, as it releases less toxic gases, potentially contributing to global warming control (Poon et al., 2007; Santos, 2008).

As it has only recently become of interest, research related to biodiesel toxicity in aquatic organisms, including fish, is still scarce. Some studies point to lower toxicity and higher biodegradability of biodiesel and its mixtures, assessed at various ratios, compared to conventional diesel (Khan, Warith, \& Luk, 2007; Santos, 2008; Swanson, Madden, \& Ghio, 2007).

The curimba (Prochilodus lineatus) is noteworthy among several fish species of economic and social interest. This is a piracema fish widely distributed throughout Latin America, more frequent in the upper Paraná River basin, which comprises the Grande, Pardo and Mogi-Guaçu Rivers. It is a low trophic level limnophagus or iliophagus (detritivorous) species, which feeds on organic material in its natural environment. Among native Brazilian fish, the curimba has displayed good results in aquaculture-related research, due to its rapid growth in intensive cultivation conditions and high management hardiness and fertility (Galdioli, Hayashi, \& Soares, 2002).

Due to the lack of information on biodiesel effects on neotropical freshwater fish species, experimental studies concerning the impact of different biofuel concentrations on fish have become necessary. In this context, this study 
aimed to assess the effect of different soluble biodiesel fraction (SBF) concentrations from burned soybean oil on the embryonic development of curimba (Prochilodus lineatus).

\section{Material and Methods}

\subsection{Biodiesel and Soluble Biodiesel Fractions (SBF)}

The biodiesel sample was obtained from the Federal University of Lavras Biofuel Laboratory, through the methylation of the soybean oil used in frying, so it was neither standardized nor purified. Its chemical composition is presented in Table 1 .

Table 1. Analytical biodiesel results

\begin{tabular}{llll}
\hline Parameter & Unit & Result & Methodology \\
\hline Ethanol & $\% \mathrm{v} / \mathrm{v}$ & Not detected & CG \\
Sodium hydroxide & $\mathrm{mg} / \mathrm{L}$ & Not detected & Titulometry \\
Lipids & $\mathrm{g} / 100 \mathrm{~mL}$ & 0.003 & IAL 032-34/IV \\
Methanol & $\% \mathrm{v} / \mathrm{v}$ & 0.24 & POP. CROMO.14 \\
\hline
\end{tabular}

Source: HIDROCEPE Analysis report no. 12571 (04/02/2013)

The soluble biodiesel fraction (SBF) separation methodology followed Simonato et al. (2011), with modifications, and was carried out at the UNIFOR Chemistry Laboratory (Centro Universitário de Formiga/MG). Briefly, a portion of the biodiesel sample was mixed with four parts of water and homogenized with a magnetic stirrer for 45 minutes. The solution was then placed in a decanter for 60 minutes and the soluble fraction was removed, discarding the supernatant. The biodiesel concentration in the stock solution was of $0.0645 \mathrm{~g} / \mathrm{L}$.

\subsection{Experimental Design}

The experiment was carried out in January 2012, at the Eletrobrás-Furnas Fish and Hydrobiology Station, located in the municipality of São José da Barra, MG. Climatic characteristics: Minimum temperature $18^{\circ} \mathrm{C}$; maximum temperature $25^{\circ} \mathrm{C}$; rainfall $278 \mathrm{~mm}$ (Climatempo, 2013).

During the experiment, water physico-chemical parameters (dissolved oxygen, $\mathrm{pH}$ and temperature) were measured every two hours with the aid of a multiparameter YSI 85 probe. The mean values in the incubators were temperature $23.0 \pm 0.1^{\circ} \mathrm{C}$; dissolved oxygen $4.58 \pm 0.34 \mathrm{mg} \mathrm{L}^{-1}$ and $\mathrm{pH} 7.3 \pm 0.1$.

\subsection{Embryos}

Embryos were obtained by induced reproduction. Breeding animals were maintained in approximately 1,000 liter-tanks, with water input, constant aeration and at $25^{\circ} \mathrm{C}$, at a ratio of two males to one female. Crude carp pituitary extract hormone was used for spawning induction. Two doses at $14 \mathrm{~h}$ intervals at $0.5 \mathrm{mg} / \mathrm{kg}$ were applied for the females, while only one dose was applied at the same time as the second dose in females for the males, at 3 $\mathrm{mg} / \mathrm{kg}$. Thus, spawning occurred semi-naturally. The oocytes were then collected and transferred to an experimental incubation system for fish embryos (Pat Req. BR102013017858-6) made of duplicate PVC with constant aeration containing different SBF concentrations, based on Masouleh et al. (2011), according to Table 2.

Table 2. SBF concentrations used in the experiment

\begin{tabular}{lll}
\hline Treatment & Concentration & Dilution factor \\
\hline Solution I & Tank water (control) & 0 \\
Solution II & $0.0645 \mathrm{~g} \cdot \mathrm{L}^{-1}$ biodiesel & $1 / 1000$ \\
Solution III & $0.129 \mathrm{~g} \cdot \mathrm{L}^{-1}$ biodiesel & $1 / 500$ \\
Solution IV & $0.645 \mathrm{~g} \cdot \mathrm{L}^{-1}$ biodiesel & $1 / 100$ \\
Solution V & $1.29 \mathrm{~g} \cdot \mathrm{L}^{-1}$ biodiesel & $1 / 50$ \\
Solution VI & $6.45 \mathrm{~g} \cdot \mathrm{L}^{-1}$ biodiesel & $1 / 10$ \\
\hline
\end{tabular}


For the SBF test, $180 \mathrm{ml}$ of solution were added to each incubator, along with the SBF concentrations and an average of 250 eggs counted under an Olympus SZ $51^{\circledR}$ stereomicroscope.

Fertilization rates (FR) were verified after eight hours post-fertilization (hpf), while hatching rates (HR) were observed at $18 \mathrm{~h}$ and 40 min post-fertilization, using random embryo and larvae sampling $(\mathrm{n} \geq 74)$, under an Olympus SZ $51{ }^{\circledR}$ stereomicroscope according to the following formulas (Felizardo, Mello, Murgas, \& Andrade, 2010):

Fertilization Rate $=[$ number of viable embryos/(number of viable embryos + number of non-viable eggs) $] \mathrm{x} 100(1)$

Hatching Rate $=[$ number of larvae/(number of larvae + number of eggs lost) $] \times 10$

To assess possible changes in embryonic development, samples were collected at $2 \mathrm{~h}$ intervals and fixed in Karnowisky's solution. The embryos were photographed with a ZEIZZ Axion Cam ERC 5G digital camera, using an AXIO ZEIZZ binocular stereomicroscope Model Lab. A1. The yolk diameter and height in oocytes and embryos were measured using the free software Image $\mathrm{J}$ (version 1.6.0).

An ANOVA test was performed and means were compared by the Tukey test to verify statistical differences (5\% significance).

\section{Results}

\subsection{Fertilization Rates}

Fertilization rate results after eight hpf are presented in Table 3.

Table 3. Fertilization rates (\%) of curimba (P. lineatus) submitted to increasing soluble biodiesel fraction concentrations

\begin{tabular}{|c|c|}
\hline Treatments & Fertilization rates $(\%)$ \\
\hline Tank water (control) & $72.73 \mathrm{a}$ \\
\hline 0.0645 g..$L^{-1}$ & $81.61 \mathrm{a}$ \\
\hline 0.129 g. $\mathrm{L}^{-1}$ & $72.97 \mathrm{a}$ \\
\hline $0.645 \mathrm{~g} \cdot \mathrm{L}^{-1}$ & $57.69 \mathrm{~b}$ \\
\hline 1.29 g. $\mathrm{L}^{-1}$ & $53.03 \mathrm{~b}$ \\
\hline 6.45 g. $\mathrm{L}^{-1}$ & $50.88 \mathrm{~b}$ \\
\hline
\end{tabular}

${ }^{*} \mathrm{p}<0.05$. Means followed by the same letters do not differ statistically by Tukey's test.

Similar fertilization rates were observed for treatments I, II and III ( $p>0.05)$, differing from treatments IV, V and VI, which were not significantly different amongst themselves $(p>0.05)$. Fertilization rates changed $(p<0.05)$ from the IV group, reducing the number of curimba embryos.

\subsection{Hatching Rate}

Hatching rates are presented in Table 4. All groups differed statistically from group I. However, group VI, exposed to $6.45 \mathrm{gL}^{-1}$ biodiesel, presented the lowest means of the experiment $(\mathrm{p}<0.0001)$

Table 4. Hatching rates (\%) of curimba (P. lineatus) eggs submitted to increasing soluble biodiesel fraction concentrations

\begin{tabular}{ll}
\hline Treatments & Hatching rates (\%) \\
\hline Tank water (control) & $46.26 \mathrm{a}$ \\
0.0645 g.L ${ }^{-1}$ & $25.73 \mathrm{~b}$ \\
$0.129 \mathrm{~g} . \mathrm{L}^{-1}$ & $29.87 \mathrm{~b}$ \\
$0.645 \mathrm{~g} . \mathrm{L}^{-1}$ & $30.58 \mathrm{~b}$ \\
$1.29 \mathrm{~g} . \mathrm{L}^{-1}$ & $31.18 \mathrm{~b}$ \\
$6.45 \mathrm{~g} . \mathrm{L}^{-1}$ & $7.56 \mathrm{c}$ \\
\hline
\end{tabular}

$* \mathrm{p}<0.05$. Means followed by the same letters do not differ statistically by Tukey's test. 


\subsection{Embryonic Development}

In the present study, an SBF effect on the embryonic development of curimba was observed, as presented in Table 5 .

Table 5. Embryonic development stages of curimba (P. lineatus) exposed to increasing soluble biodiesel fraction concentrations

\begin{tabular}{|c|c|c|c|c|c|c|}
\hline HPF1 & I4 & II 4 & III4 & IV4 & V4 & VI4 \\
\hline 2 & 128 cel. & $128 \mathrm{cel}$. & 64 cel. & High & 128 cel. & $128 \mathrm{cel}$. \\
\hline 4 & Oblong & Oblong & High & High & High & Oblong \\
\hline 6 & $50 \%$ & $50 \%$ & $60 \%$ & $50 \%$ & $30 \%$ & $50 \%$ \\
\hline 8 & $50 \%$ & $50 \%$ & $60 \%$ & $60 \%$ & $60 \%$ & $50 \%$ \\
\hline 10 & $\mathrm{BC} 2$ & $\mathrm{BC} 2$ & $\mathrm{BC} 2$ & $\mathrm{BC} 2$ & $\mathrm{BC} 2$ & $80 \%$ \\
\hline 12 & $10 \mathrm{~S} 3$ & $5 \mathrm{~S} 3$ & FB2 & $10 \mathrm{~S} 3$ & $3 \mathrm{~S} 3$ & $\mathrm{BC} 2$ \\
\hline 14 & $15 \mathrm{~S} 3$ & $10 \mathrm{~S} 3$ & $10 \mathrm{~S} 3$ & $10 \mathrm{~S} 3$ & $10 \mathrm{~S} 3$ & $\mathrm{BC} 2$ \\
\hline 16 & $20 \mathrm{~S} 3$ & $20 \mathrm{~S} 3$ & $20 \mathrm{~S} 3$ & $18 \mathrm{~S} 3$ & $16 \mathrm{~S} 3$ & $13 \mathrm{~S} 3$ \\
\hline 18 & Larvae & $25 \mathrm{~S} 3$ & $25 \mathrm{~S} 3$ & $19 \mathrm{~S} 3$ & $18 \mathrm{~S} 3$ & $18 \mathrm{~S} 3$ \\
\hline
\end{tabular}

$1 \mathrm{HPF}$ - hours post-fertilization; $2 \mathrm{FB}$ - blastopore closure; $3 \mathrm{~S}$ - somites; 4 - Treatments.

After two hpf, almost all embryos comprised approximately 128 cells, except for those who underwent treatment III, displaying 64 cells. At four hpf, changes in embryo development were observed, with treatments II, VI and control already in the oblong phase, while the others were in the high phase (Figure 1).
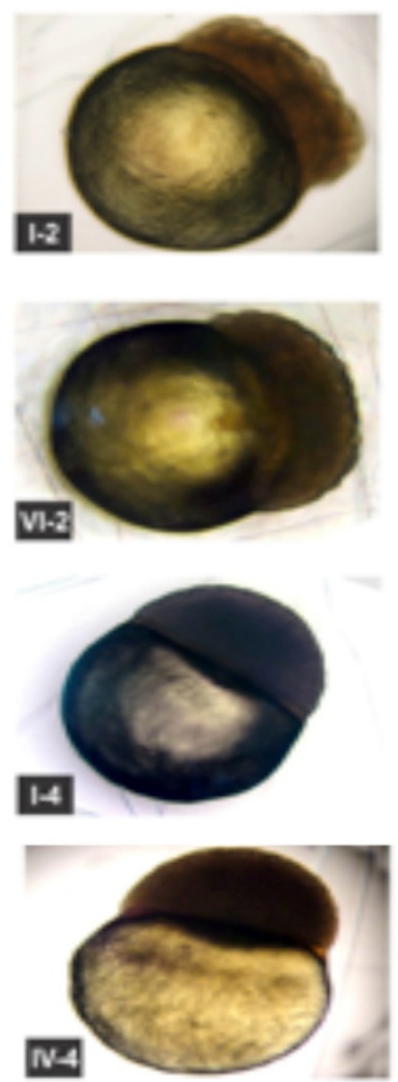
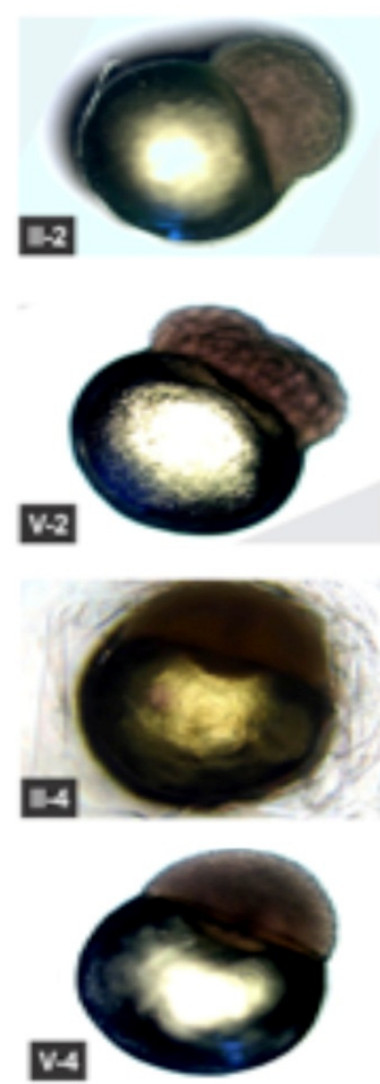
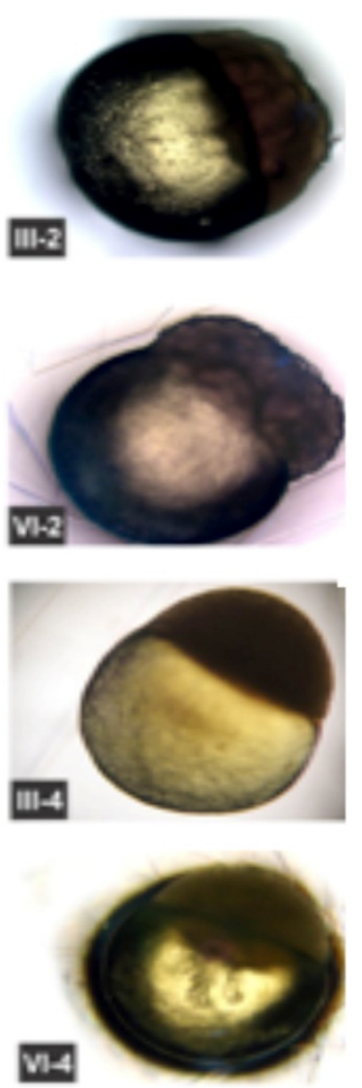

Figure 1. Blastula stage of oocytes submitted to increasing soluble biodiesel fraction concentrations 
In the gastrula stage, all embryos were around 50\% epiboly, from six hpf to eight hpf (Figure 2).
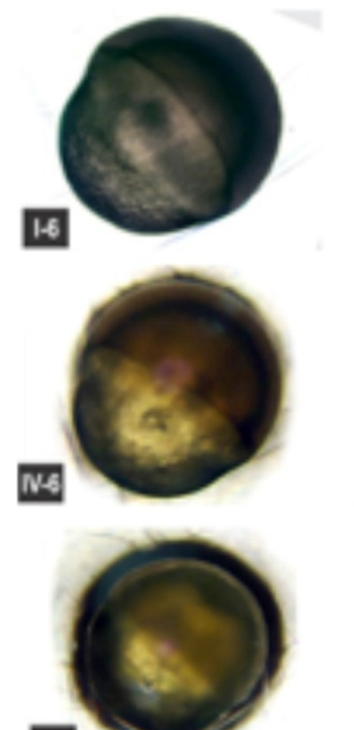

18

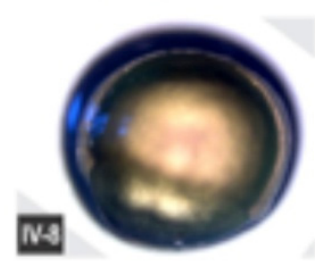

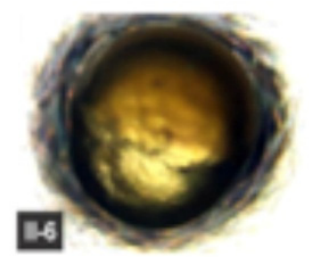
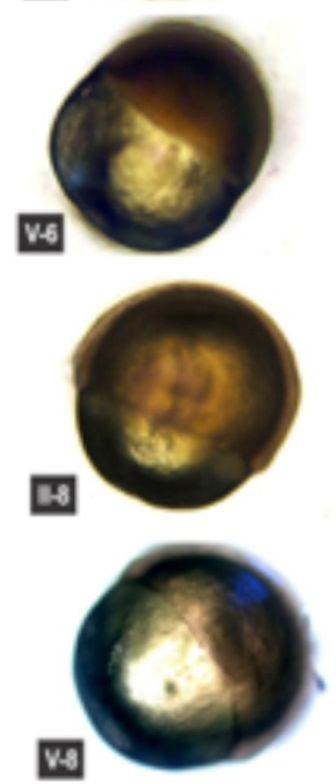
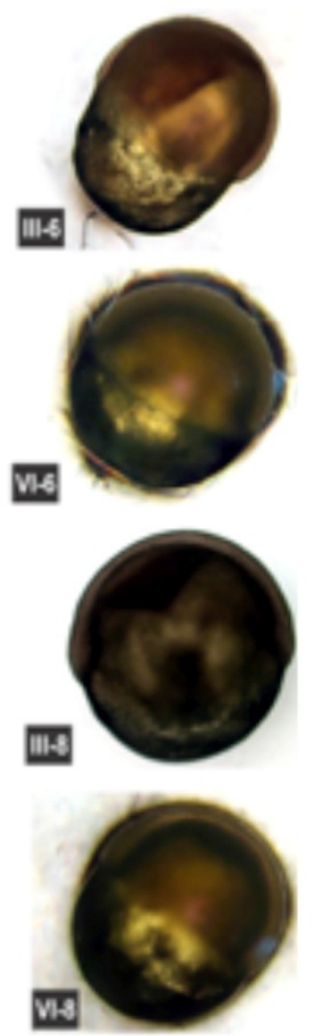

Figure 2. Gastrula phase of oocytes submitted to increasing soluble biodiesel fraction concentrations

From the tenth hpf, delays in embryo development were evidenced in relation to the control treatment. Embryos that underwent treatment VI displayed $80 \%$ epiboly, differing from the other treatments, which were in the blastopore closure phase. The segmentation stage of the embryos is presented in Figures 3 and 4.
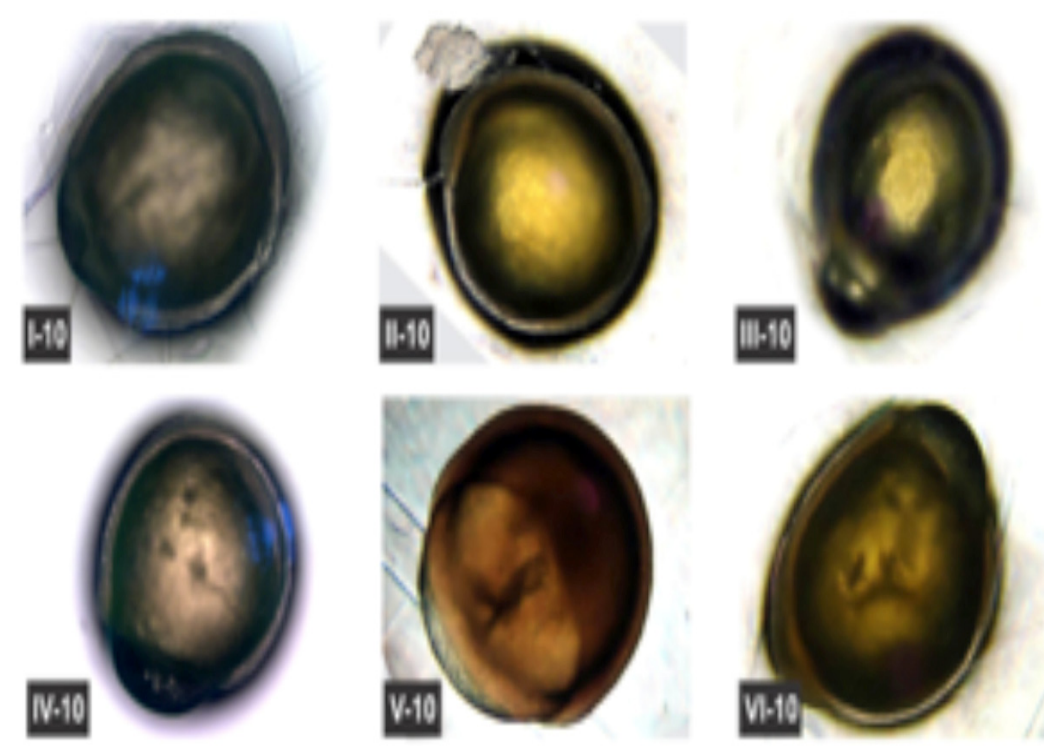

Figure 3. Segmentation stages of embryos submitted to increasing soluble biodiesel fraction concentrations 


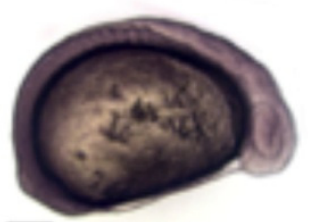

12

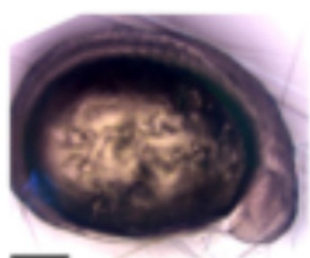

(N.12

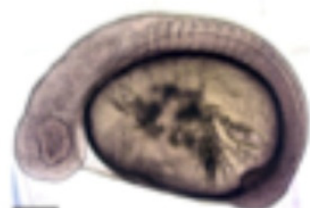

14
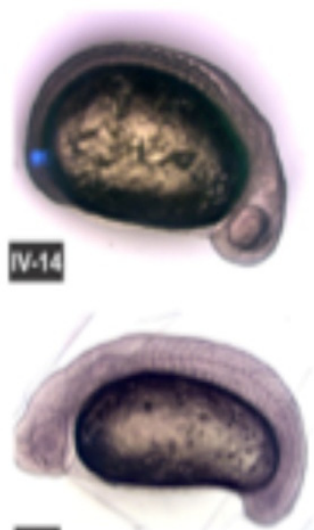

H10

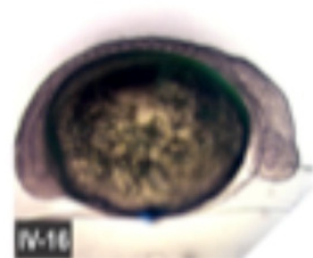

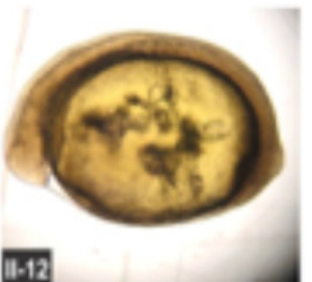
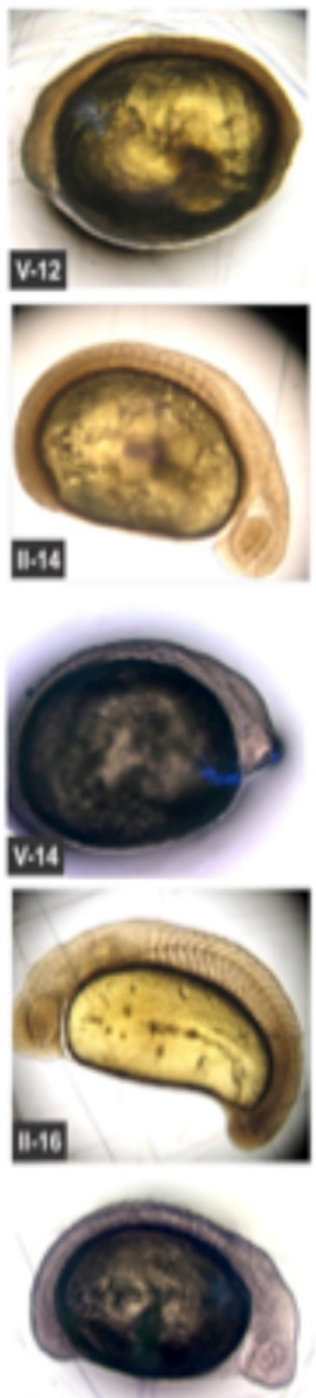

V.10
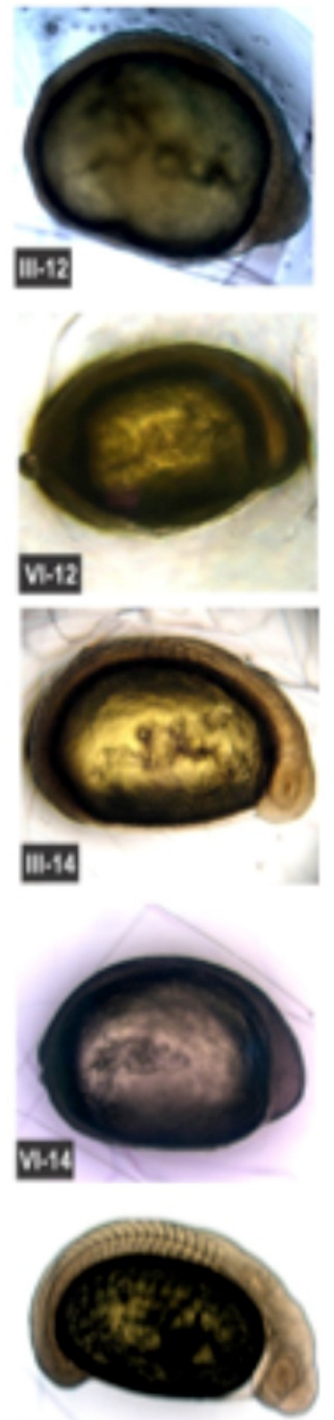

(in+10

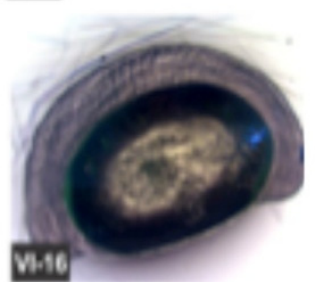

Figure 4. Segmentation and organogenesis phases of embryos submitted to increasing soluble biodiesel fraction concentrations

From 12 hpf to 14 hpf, developmental delays occurred (Figure 5) and a striking difference was observed, since embryos that underwent treatment VI were in the blastopore closure phase, while embryos that underwent the other treatments, as well as those in the control group, were in the somite development phase. At $16 \mathrm{hpf}$, the embryos advanced in their development, similar to the embryos from the control group.

From $18 \mathrm{hpf}$, the control embryos had already reached the larval stage, while embryos that underwent SBF treatments were still in the phase presenting 18 to 25 somites. 

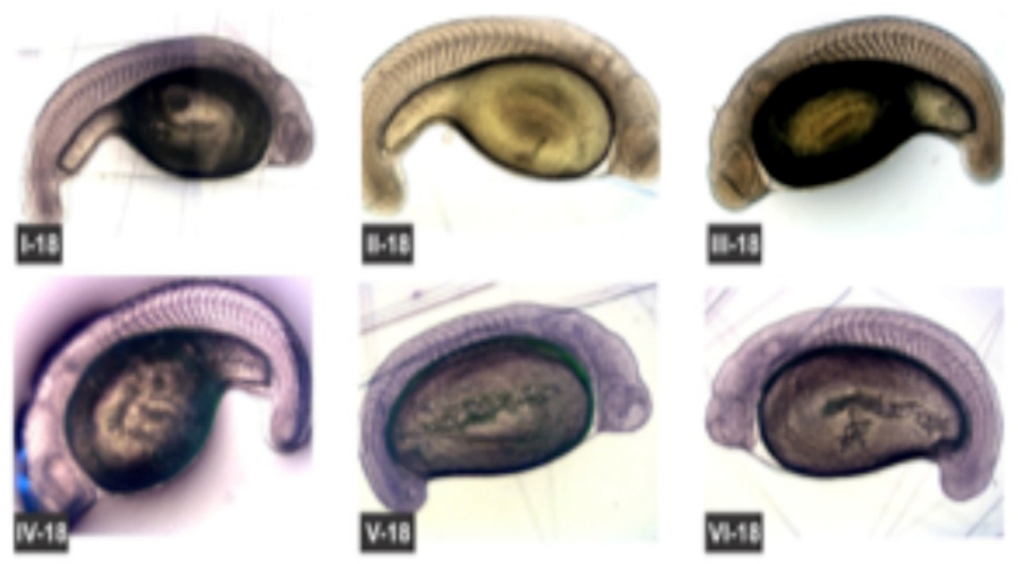

Figure 5. Larval phase of P. lineatus exposed to increasing increasing soluble biodiesel fraction concentrations

Total embryonic development, from fertilization to hatching, took $18 \mathrm{~h}$ and $40 \mathrm{~min}$.

\section{Discussions}

The values observed in the present study concerning fertilization rates ranged from 50.88 to $81.61 \%$, similar to those reported by Paulino et al. (2011) and Silva et al. (2009), respectively, of $40 \pm 5 \%$ and $40-50 \%$. However, they contrast from the results reported by Souza (2007), of $94.77 \%$. Although fertilization rates did not differ between the control group and treatments II and III, treatments II and III exerted a negative effect on embryonic development with regard to hatching rates. The hatching rates observed herein differ from the values reported by Silva et al. (2009); Meireles et al. (2011); Paulino et al. (2011); Hernandez Cuadrado (2013), that ranged from $50.88 \%$ to $95.00 \%$. According to Rand and Petrocelli (1985), toxic biofuel effects include lethality (mortality) and sublethal effects, such as changes in growth, development, reproduction, pathological, biochemical and behavioral responses. However, the lack of studies in this area makes it difficult to directly compare results, considering the difference in the composition of the assessed biofuels, differences in methodologies and organism variations.

Biodiesel effects on fertilization, hatching, and developmental rates were significant since, generally, these rates in laboratory and controlled conditions were high and reduced with increasing SBF concentrations. Embryos and fish larvae are susceptible to chemical compound effects (McKim, 1977) as well as gametes released into the water column that come into contact with the dispersed contaminant, reducing fertilization success (Lewis, Pook, \& Galloway, 2008). Therefore, direct embryo exposure can be inferred to result in decreased reproduction rates and embryonic development, which could lead to future population reductions.

At two hours post-fertilization (hpf) almost all embryos comprised approximately 128 cells, except for treatment III, comprising 64 cells. Four hours after fertilization, changes in embryo development were observed, although slight, as embryos in treatments II, VI and controls were already in the oblong phase, while the others were in the high phase, very similar to the results obtained by Ninhaus-Silveira et al. (2006); Botta et al. (2010) and Hernandez Cuadrado (2013).

The lowest biodiesel concentrations (treatments II and III) did not lead to macroscopic embryo changes after eight hpf. These assessments as carried our herein are effective in observing differences between viable and non-viable eggs, but the effect of increasing biodiesel concentrations in the form of turbidity of the aqueous medium masked fertilization rate readings, as, according to Meirelles et al. (2011) Curimba produces opaque, gray-colored oocytes and embryos are translucent and transparent.

In the first $10 \mathrm{hpf}$, embryos from all treatments displayed similar development to the controls, which were, in turn, similar to those observed by Ninhaus-Silveira et al. (2006); Botta et al. (2010) and Hernandez Cuadrado (2013), even when working in different temperatures.

From the tenth hpf, delays in embryo development were evidenced in relation to the control treatment. Embryos who underwent treatment VI displayed $80 \%$ epiboly, differing from embryos that underwent the other treatments, which were in the blastopore closure phase. Lewis et al. (2008) reported that crude oil (water-rich fraction) reduces post-fertilization rates and leads to teratogenic effects in early embryonic stages, where embryos exhibit abnormal cleavage patterns and high levels of fluctuating asymmetry. 
The embryonic development period from fertilization to hatching observed herein was different from that reported for the same species by other authors, where Ninhaus-Silveira et al. (2006) reported a total of $22 \mathrm{~h}$ at $24^{\circ} \mathrm{C}$ and $14 \mathrm{~h}$ for $28^{\circ} \mathrm{C}$, while Botta et al. (2010) reported $18 \mathrm{~h}$ at $25^{\circ} \mathrm{C}$, with incubation period being dependent on water temperature.

\section{Conclusion}

Different SBF concentrations from burnt soybean oil lead to alterations in the embryonic Curimba (Prochilodus lineatus) development. Although biodiesel and its mixtures are less toxic that diesel and petroleum, they are, however, detrimental to Curimba (Prochilodus lineatus) embryos, and risks to other aquatic organisms should be taken into account. Further studies focusing on biodiesel toxicity should be performed in order to elucidate its effects on aquatic organisms.

\section{Acknowlegements}

This work was supported by the Conselho Nacional de Desenvolvimento Científico e Tecnológico (CNPq), the Coordenação de Aperfeiçoamento de Nível Superior (CAPES) and the Fundação de Amparo à Pesquisa do Estado de Minas Gerais (FAPEMIG).

\section{Conflict of interests}

The authors declare that there is no conflict of interests regarding the publication of this paper.

\section{References}

Botta, P., Sciara, A., \& Arranz, S. (2010). Estúdio del desarrollo embrionário del sábalo (Prochilodus lineatus). Archivos de Medicina Veterinaria, 42, 109-114.

Climatempo. (2013). Retrieved from http://www.climatempo.com.br

Felizardo, V. O., Mello, R. A., Murgas, L. D., \& Andrade, E. S. (2010). Effect of cryopreservant combinations on the motility and morphology of curimba (Prochilodus lineatus) sperm. Animal Reproduction Science, 122(3/4), 259-263.

Galdioli, E. M., Hayashi, C., \& Soares, C. M. (2002). Substituição da proteína do farelo de soja pela proteína do farelo de canola em rações para alevinos de curimbatá (Prochilodus lineatus V.). Revista Brasileira de Zootecnia, 31(2), 552-559.

Hernández Cuadrado, E. E. (2013). Indução da atividade espermática e desenvolvimento embrionário e larval de curimba (Prochilodus lineatus). (PhD), Universidade Federal de Lavras, Lavras.

Khan, N., Warith, M., \& Luk, G. (2007). A comparison of acute toxicity of biodiesel, biodiesel blends, and diesel on aquatic organisms. Journal of the Air \& Waste Management Association, 57, 286-296.

Lewis, C., Pook, C., \& Galloway, T. (2008). Reproductive toxicity of the water accommodated fraction (WAF) of crude oil in the polychaetes Arenicola marina (L.) and Nereis virens (Sars). Aquatic Toxicology, 90, 73-81.

Masouleh, F. F., Amiri, B. M., Mirvaghefi, A. R., \& Nemtollahi, M. A. (2011). In vitro effects of diazinon on male reproductive tissue and sperm motility of caspian kutum (Rutilus frisii kutum). Research Journal of Environmental Toxicology, 5, 108-116.

McKim, J. M. (1977). Evaluation of tests with early life stages of fish for predicting long-term toxicity. Journal of the Fisheries Board of Canada, 34, 1148-1154.

Meireles, W. A., Santos, L. X., Fogueiredo, S. A., \& Buteri, C. B. (2011). Reprodução induzida de alguns peixes migradores das bacias dos rios Pardo e Jequitinhonha. V\&Z Minas, Belo Horizonte, 21(108), 38-42.

Ninhaus-Silveira, A., Foresti, F., \& Azevedo, A. (2006). Strutural and ultrastrutural analysis of embryonic developmente of Prochilodus lineatus (Valenciennes, 1836) (Characiforme; Prochiloldontidae). Zygote, 14, 217-229.

Paulino, M. S., Miliorini, A. B., \& Murgas, L. D. S. (2011). Desempenho reprodutivo do pacu, piracanjuba e curimba induzidos com extrato de buserelina. Boletim do Instituto de Pesca, 37(1), 39-45.

Poon, R., Chu, I., Valli, V. E., Graham, L., ..., \& Fingas, M. (2007). Effects of three biodiesels and a low sulfur diesel in male rats - A pilot 4-week oral study. Food and Chemical Toxicology, 45, 1830-1837.

Rand, G. M., \& Petrocelli, S. R. (1985). Fundamentals of aquatic toxicology: Methods and applications. Washington: Hemisphere. 
Santos, F. A. (2008). Biocombustiveis: Prós e contras. Retrieved from http://home.utad.pt/ fsantos/pub-fas/Biocombustiveis.pdf

Silva, J. M. de A., Murgas, L. D. S., \& Felizardo, V. de O. (2009). Características seminais e índices reprodutivos de curimba (Prochilodus lineatus) em diferentes períodos reprodutivos. Revista Brasileira de Saúde e Produção Animal, 10(3), 668-677.

Simonato, J. D., Albinati, A. C., \& Martinez, C. B. R. (2011). Effects of the water soluble fraction of diesel fuel oil on some functional parameters of the neotropical freshwater fish Prochilodus lineatus Valencianes. Bulletin of Environmental Contamination and Toxicology, 76, 505-511.

Souza, B. E. (2007). Fertilização artificial em ovócitos de curimbatá (Prochilodus lineatus). (Master's), Universidade Estadual Paulista, Jaboticabal.

Swanson, K. J., Madden, M. C., \& Ghio, A. J. (2007). Biodiesel exhaust: The need for health effects research. Environmental Health Perspectives, 115(4), 496-499.

Teixeira, M. C., \& Touil, D. S. G. (2010). Biodiesel: Uma alternativa verde. Vértices, 12(3), 17-40.

\section{Copyrights}

Copyright for this article is retained by the author(s), with first publication rights granted to the journal.

This is an open-access article distributed under the terms and conditions of the Creative Commons Attribution license (http://creativecommons.org/licenses/by/4.0/). 